\title{
Positioning Bio-Based Energy Systems in a Hypercomplex Decision Space-A Case Study
}

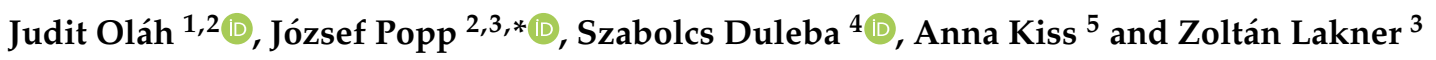 \\ 1 Faculty of Economics and Business, University of Debrecen, 4032 Debrecen, Hungary; \\ olah.judit@econ.unideb.hu \\ 2 College of Business and Economics, University of Johannesburg, Johannesburg 2006, South Africa \\ 3 Faculty of Economics and Social Sciences, Szent István University, 2100 Gödöllő, Hungary; \\ lakner.zoltan.karoly@uni-mate.hu \\ 4 Department of Transport Technology and Economics, Faculty of Transportation Engineering and Vehicle \\ Engineering, Budapest University of Technology and Economics, 1111 Budapest, Hungary; \\ duleba.szabolcs@mail.bme.hu \\ 5 Department of Science Policy and Scientometrics, Library and Infromation Centre of the Hungarian Academy \\ of Sciences, 1051 Budapest, Hungary; kiss.anna891@gmail.com \\ * Correspondence: popp.jozsef@uni-mate.hu
}

Citation: Oláh, J.; Popp, J.; Duleba, S.; Kiss, A.; Lakner, Z. Positioning Bio-Based Energy Systems in a Hypercomplex Decision Space-A Case Study. Energies 2021, 14, 4366. https://doi.org/10.3390/en14144366

Academic Editor: François Vallée

Received: 30 May 2021

Accepted: 16 July 2021

Published: 20 July 2021

Publisher's Note: MDPI stays neutral with regard to jurisdictional claims in published maps and institutional affiliations.

Copyright: (c) 2021 by the authors. Licensee MDPI, Basel, Switzerland. This article is an open access article distributed under the terms and conditions of the Creative Commons Attribution (CC BY) license (https:// creativecommons.org/licenses/by/ $4.0 /)$.

\begin{abstract}
The optimization of the energy portfolio for a small, open, landlocked economy with rather limited fossil resources is a complex task because it must find a long-range, sustainable balance between the various goals of society under the constant pressure of different interest groups. The opinions of independent, informed experts could be an essential input in the decision-making process. The goal of this research was to determine the relative importance of the values and goals potentially accompanying projects, based on the utilization of bioenergy. The current research is based on a wide-ranging survey of 65 non-partisan experts, applying the Pareto analytic hierarchy process to ensure the unbiased prioritization of project segments. The results of the survey put a spotlight on the importance of the economic role of bioenergy projects. Contrary to previous expectations and considerations, the social functions of these projects have hitherto been given relatively little importance. The results highlight the importance of bioenergy in increasing the income-generating capacity of agricultural producers by optimal utilization of natural resources for agricultural production. This can be achieved without considerable deterioration of the natural environment. Modern agricultural production is characterized by high levels of mechanization and automatization. Under these conditions, the social role of bioenergy projects (job creation) is rather limited.
\end{abstract}

Keywords: analytic hierarchy process; bibliometrics; complex decision making; environmental policy; Pareto algorithm; strategy formation

\section{Introduction}

Supra-, national- or community-level decisions related to the application of biological resources for energy production (bioenergy, or BE) must deal with complex questions related to climate and energy policies. Both are specific realms due to following reasons: Firstly, according to a widely accepted statement, the climate-change-human interaction is a hypercomplex problem [1,2]. It has numerous, non-directly quantifiable (measurable) aspects, as noted by Christophers [3], and, by definition, should be considered as a nonlinear phenomenon [4], for the reason that "human decisions, ideas and interventions can (and have done in history) literally change the course of the world" [5]. Secondly, energy policy discussions have, for a long time, been limited to engineering and economic [6] problems; however, this approach does not provide justice in terms of the decisions reached. In the opinion of Jones et al. [7], the basic dimensions of justice in energy policy decisions 
are related to distributive, procedural and cosmopolitan aspects. Sovacool and Brown [8] advocate for an energy justice framework based on availability, affordability, due process, transparency and accountability, sustainability, intra- and intergenerational equity and responsibility, serving the futurity, fairness and equity dimensions of energy production. Sovacool et al. [9] have proven that the concept of energy justice is deeply interwoven into philosophy, reflecting deep-rooted values such as virtue, utility, human rights, welfare, happiness, freedom and fairness.

The problems of energy policy are closely linked to the United Nations (UN) sustainable development goals [10]. The most important aspects of the UN 2030 agenda and bioenergy projects are summarized in Table 1.

Table 1. The UN sustainable development goals and the question of bioenergy production.

\begin{tabular}{|c|c|}
\hline $\begin{array}{l}\text { UN } 2030 \text { Agenda for Sustainable } \\
\text { Development }\end{array}$ & Aspects of Bioenergy Policy \\
\hline "Eradicate extreme poverty" & $\begin{array}{l}\text { Bioenergy production can contribute to the } \\
\text { creation of new workplaces [11]. }\end{array}$ \\
\hline $\begin{array}{l}\text { "Enhance the resilience of the poor and those } \\
\text { in vulnerable situations and reduce their } \\
\text { exposure and vulnerability to climate-related } \\
\text { extreme events and other economic, social and } \\
\text { environmental shocks" }\end{array}$ & $\begin{array}{l}\text { Bioenergy programs can reduce rural poverty } \\
\text { [12]. }\end{array}$ \\
\hline "Ending hunger, achieving food security" & $\begin{array}{l}\text { Bioenergy crops compete with food and feed } \\
\text { production [13]. }\end{array}$ \\
\hline $\begin{array}{l}\text { "Healthy lives, and the promotion of } \\
\text { well-being for all" }\end{array}$ & $\begin{array}{l}\text { The application of bioethanol could contribute } \\
\text { to the emission of harmful gases [14]. }\end{array}$ \\
\hline "Sustainable management of water" & $\begin{array}{l}\text { Irrigation can have negative consequences for } \\
\text { the structure of soil [15]. }\end{array}$ \\
\hline $\begin{array}{l}\text { "Ensure access to affordable, reliable, } \\
\text { sustainable and modern energy for all" }\end{array}$ & $\begin{array}{l}\text { A bioenergy program can contribute to the } \\
\text { enhancement of the energy independence of } \\
\text { different countries [16]. }\end{array}$ \\
\hline $\begin{array}{l}\text { "Promote sustained, inclusive and sustainable } \\
\text { economic growth, full and productive } \\
\text { employment and decent work for all" }\end{array}$ & $\begin{array}{l}\text { An efficient bioenergy supply system can be an } \\
\text { important contributor to economic growth, } \\
\text { based on the accelerative and multiplicative } \\
\text { effects of BE programs [17]. }\end{array}$ \\
\hline $\begin{array}{l}\text { "Inclusive and sustainable industrialization, } \\
\text { fostering innovation" }\end{array}$ & $\begin{array}{l}\text { The development of a bioenergy program is, } \\
\text { per se, a contributor to industrialization and } \\
\text { innovation, especially in rural areas [18]. }\end{array}$ \\
\hline "Reduce economic inequality" & $\begin{array}{l}\text { BE programs could contribute to regional } \\
\text { economic development [19]. }\end{array}$ \\
\hline "Inclusive, safe, resilient and sustainable cities" & $\begin{array}{l}\text { BE projects contribute to reductions in } \\
\text { pollution [19]. }\end{array}$ \\
\hline $\begin{array}{l}\text { "Sustainable consumption and production } \\
\text { patterns" }\end{array}$ & $\begin{array}{l}\text { BE could contribute to sustainable } \\
\text { consumption and production, but the practical } \\
\text { reality of this is an open-ended question [20]. }\end{array}$ \\
\hline "Combat climate change and its impacts" & $\begin{array}{l}\text { One of the most important motivators of } \\
\text { bioenergy projects is reducing the burden of } \\
\text { the climate [21]. }\end{array}$ \\
\hline $\begin{array}{l}\text { "Sustainable ecosystems, forest management } \\
\text { and reversion of land degradation" }\end{array}$ & $\begin{array}{l}\text { The energy forest can play an important role in } \\
\text { sustainable forest management and reducing } \\
\text { landscape degradation [22]. }\end{array}$ \\
\hline $\begin{array}{l}\text { "Effective, accountable and inclusive } \\
\text { organizations"“Sustainable bioeconomy" }\end{array}$ & $\begin{array}{l}\text { Bioenergy could contribute to the development } \\
\text { of local clusters [23].Bioenergy can sustain the } \\
\text { transition to a sustainable bioeconomy }[24,25] \text {. }\end{array}$ \\
\hline
\end{tabular}

Source: Authors' own research, 2020, based on selected references.

Analysis of the socio-economic aspects of the application of bioenergy is a highly complex question involving numerous aspects that are not directly measurable. That is why they must be considered as imponderables, the evaluation of which is highly dependent on the opinions of different specialists. The optimization of the energy portfolio is a question of 
strategic importance for each nation and is influenced by the constant pressure of different interest groups.

The aim of this paper was to demonstrate how to determine the relative importance of different factors of bioenergy in the highly complex goal system of society, and how to harmonize the goals of different segments of society in the field of bioenergy. The authors' efforts are based on global experiences with the development of bioenergy systems [26,27] and methodological advances in the field of complex decision making [28,29].

The novelty of the article is threefold: (1) the results are based on a wide-ranging, in-depth, systematic bibliometric analysis and mapping of the relevant literature related to bioenergy; (2) the calculations are based on a highly innovative approach to AHP analysis, developed by Bozóki and Fülöp [30], offering a better approximation of weight vectors than the traditional, eigenvector-based models, and thus providing the robust prioritization of bioenergy project segments; and, (3) to the best of our knowledge, this is the first attempt to determine the place and role of general bioenergy policy in the development of a small, open, landlocked economy, based on the tacit knowledge of informed, mainly non-partisan experts, as opposed to a socio-economic evaluation of individual projects.

The paper is structured as follows. The first part offers a general overview of the most important results in the field of research: the socio-economic aspects of bioenergy systems, as well as the development and application of AHP in general and in the field of bioenergy in particular. In the second part of the paper, the most important results of an expert-based survey as well as the discussion and interpretation of the survey results are presented.

\section{Literature Review}

\subsection{Bioenergy Projects in the Context of Biometric Analysis}

To evaluate the knowledge base accumulated in the field of the socio-economic aspects of bioenergy, the authors utilized the Web of Science (WoS) system (WoS, 2020). Although there are several bibliographic data collection systems included (e.g., Scopus, Microsoft Academic, OpenCitations, Dimensions, Crossref), this bibliometric database is considered a high-quality source of peer-reviewed academic publications [31,32].

The bioenergy-related articles were searched in a core collection of English articles on WoS, based on a keyword combination as follows: ((TS=)((()((()((()(“bioet") OR ("bioen$\left.\operatorname{erg}^{* \prime \prime}\right)$ ) OR ("biodies*")) OR ("biogas*")) OR ("short rotation crop" $\left.{ }^{* \prime \prime}\right)$ ) OR ("biofuel")) OR ("energytree*")) OR ("Energygrass")) OR ("energyplantation")) OR ("energy plantation")) OR ("energy forest" $\left.{ }^{*}\right)$ ) OR (("biomass") AND ("energy"))) AND ("Econom")) AND $(($ "Social") OR ("Socio*")))) AND (LA=(English))) AND (DT=(Article)) [2 047 results].

The Share of the Most Important States in Bioenergy-Related Publications

An extremely rapid expansion of publications can clearly be observed in the field of socio-economic aspects of bioenergy. However, the deep-rooted inner dynamics of different topics in the field can also be noticed. To uncover the changes in bioenergy-related socio-economic research, we applied the approach developed by [33] and widely used in bibliometric cartography [34]. Based on a co-word analysis, we suggest a clustering of the most important topics. These clusters are called themes. The themes can be characterized by two parameters: density and centrality. Density expresses the connectedness of different keywords within the same cluster, and centrality expresses the connectedness of the given topics with one another. According to their position in the centrality-density plan, the different themes can be categorized as "motor-themes" (high centrality and density), highly developed and isolated themes (high density and low centrality), emerging or declining themes (low density and centrality) and basic and transversal themes (high centrality and low density).

The last few decades can be divided into three periods: an initial period beginning with the first publication of bioenergy-related articles and extending up to the millennium. During this period, climate change became an established, widely accepted fact, and the technologies of bioenergy-based systems achieved a certain level of technological stability, 
reliability and social acceptance [35]. In the second period-between 2000 and 2008-the importance of publications related to bioenergy production rapidly increased, but in the third period, the global economic crisis and its consequences have created a new socioeconomic environment for further development, parallel with the increasing importance of climate change.

In the first phase of the research, we prepared thematic maps of the different themes using the Bibliometric $\mathrm{R}$ package for the three periods outlined above. The algorithm gave well-separable clusters, but interpretation of the different clusters proved rather difficult and unsuitable for publication; therefore, the original data have been recorded based on keywords and converted into more interpretable names. We verified this method using the natural language processing package of $\mathrm{R}$ Feinerer [36] and replaced the original keywords with more interpretable ones before dividing the dataset into a teaching set and a test set, in a 70:30 ratio. The reliability of the separation was more than $90 \%$, so we accepted the new, relatively clearly interpretable words that show the focus of the research activities.

\subsection{Bibliometric Mapping of Bioenergy Research}

The map of the most important research directions in the three time periods (1994-2000; 2001-2008; 2009-2020) is summarized in Figure 1.

The first period (1994-2000) can be characterized by a rather intensive discussion on the economic aspects of modern bioenergy systems. In this period, biofuel production was at the center of public and professional attention; therefore, the focal countries during this period were the USA and Brazil with their rapidly increasing biofuel production. This was the beginning of the never-ending food or feed dilemma, which did not become integrated into the general exchange of ideas. This is well reflected by the fact that topics related to ethical problems have a high level of centrality (numerous authors have cited articles analyzing these problems) but a low level of density, indicating a high level of "parallel monologues" instead of constructive discussions. Policy analysis appeared as a new, emerging topic at this time. Interestingly, policy- and ethics-related questions are in totally different topological positions. This fact highlights the lack of a constructive discussion between researchers on value systems and economic policies.

The second period (2001-2008) can be characterized by an abundance of different topics in a period of unprecedented global development. In this period, the most central topics were the optimization of land use policy and the analysis of the air pollution consequences of the bioenergy process. This was the era of the carbon dioxide trade boom [37]. The optimal management of capacities as well as consumer aspects were also important topics, but these problems were analyzed by a relatively closed circle of researchers. The introduction of modern econometric methods (e.g., panel cointegration) of analysis gained importance. Economic aspects of the utilization of residuals and byproducts were also studied. The ethical aspects maintained their relevance, but mainly in the context of developing states. This was a relatively important topic but could not be integrated into the general debate.

The last decade (2009-2020) can be characterized by the rise of China and India as major world powers. The integrated policy analysis of different aspects of bioenergy projects became the principal topic of research. After in-depth analysis, there is an increasing possibility of a synthetic approach [38]. The optimal utilization of biomass became a relatively hot topic within a close-knit community of researchers. System optimization seems to be a favorite topic of a relatively small group of researchers; however, their results are relatively weakly reflected in the research community.

In summary, it can be stated that the complex socio-economic analysis of bioenergy systems is a question of utmost importance, which is at the cutting edge of academic research but remains a relatively lesser studied problem, especially in the central European context. 
Results of bibliometric mapping of bioenergy-related publications from 1994 to 2000.

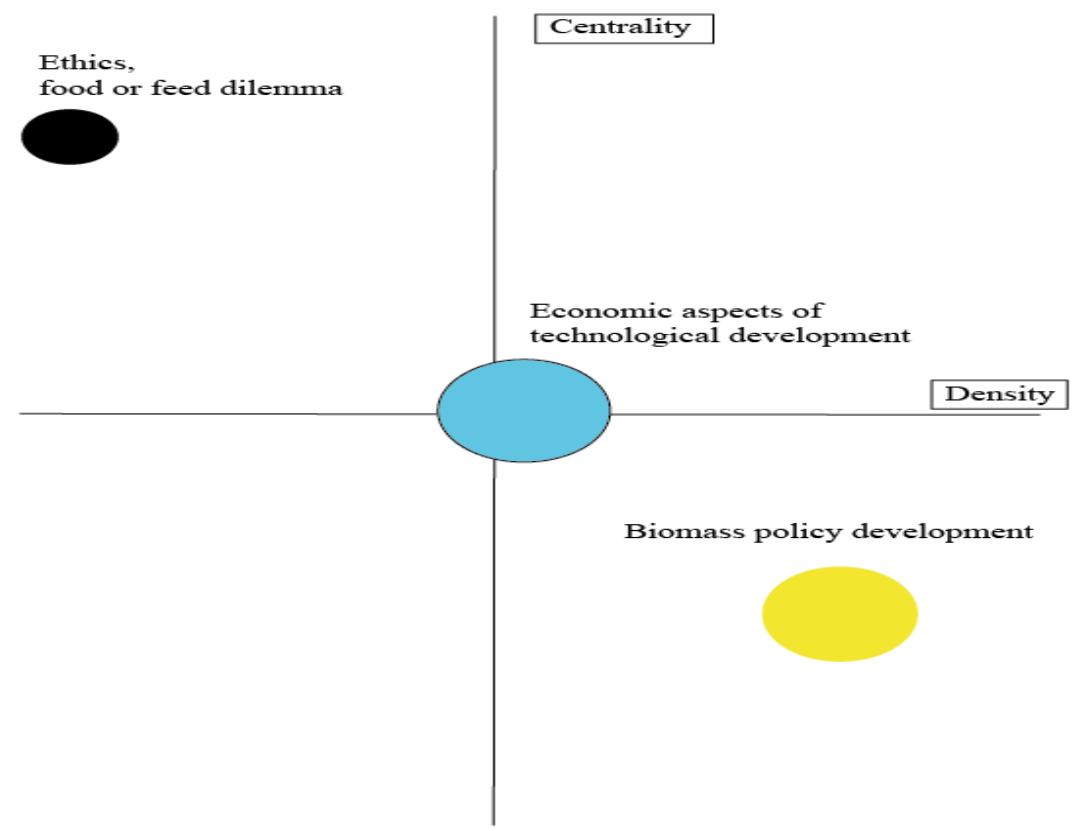

Results of bibliometric mapping of bioenergy-related publications from 2001 to 2008 .

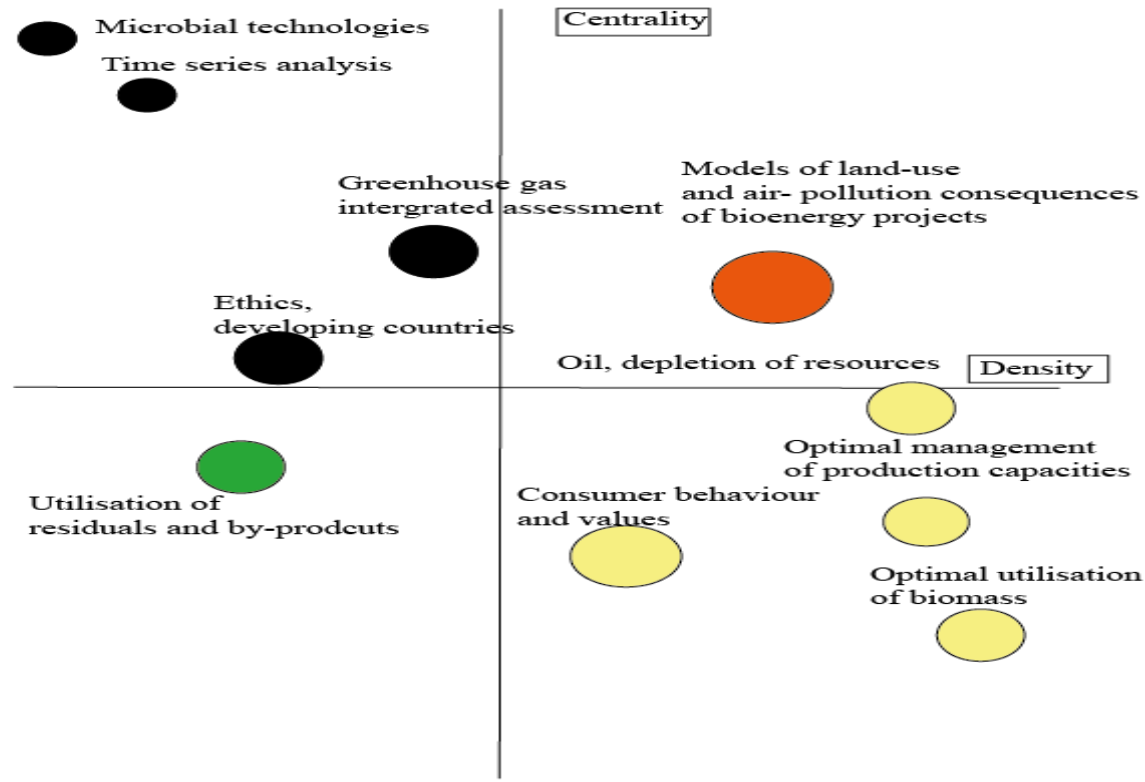

Figure 1. Cont. 
Results of bibliometric mapping of bioenergy-related publications from 2009 to 2020.

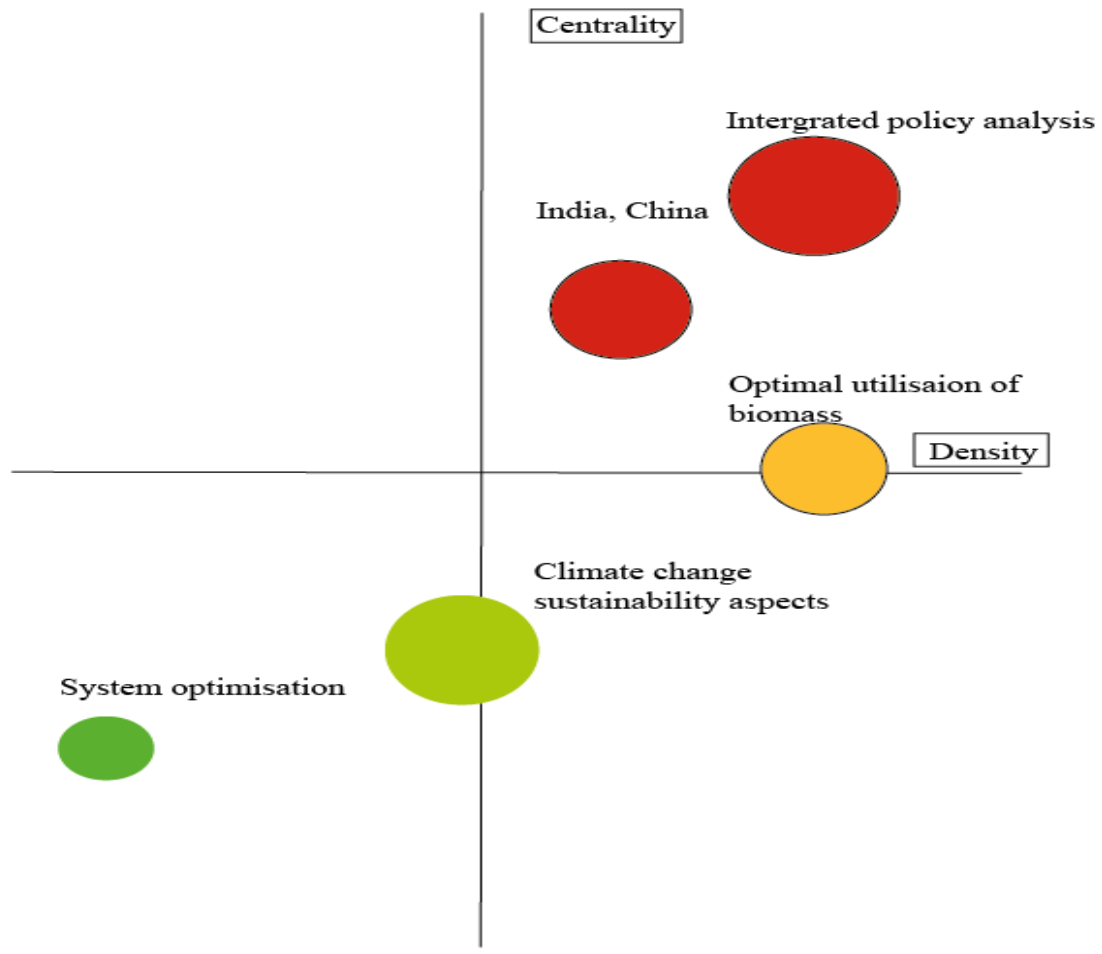

Figure 1. Results of the thematic bibliometric mapping of publications dealing with the socio-economic aspects of bioenergy (1994-2000; 2001-2008; 2009-2020).

\subsection{The Analytical Hierarchy Process: The Intellectual Evolution of an Innovative Method}

The methodology of the comparison of imponderables has been developed organically over the last few decades, but the bases of the methods have remained item theory and Thurston's complex pairwise comparison [39]. A considerable sophistication of Thurston's original idea is the AHP, developed by $[40,41]$. This method is based on the human ability to hierarchically analyze complex systems, i.e., to judge the relative importance of one object over another [42]. Since its introduction, the method has been widely applied in different fields of policy analysis [43].

Obviously, several other methods exist for the analysis of multi-criteria-decision-type problems. Among the main competitors, TOPSIS, PROMETHEE, ELECTRE and SAW can be mentioned. However, none of these methods are capable of synthesizing the ratings of large-scale evaluators (over 20) along with checking their consistency to capture a trustworthy image of the problem analyzed. A clear advantage of the AHP over all other well-proven multi-criteria methods is, on the one hand, the hierarchical decision structure, which helps the participants to understand the attributes of the problem in focus. On the other hand, there is the advantage of the threshold of violating the transitivity in the scoring of the criteria and alternatives. In the next section, we stress this consistency check by formulas (4) and (5). In all AHP applications, we first compute the consistency ratio and filter all evaluations that do not correspond to the minimum degree of consistency. Consequently, only those scores are computed that fulfil the condition of a sufficiently transitive rating. All the other techniques utilize less hard or no filtering of non-transitive preference expressions.

In this part of the study, attention is paid to the application of the AHP in the energy sector in general and in biofuel production in particular. The AHP is widely used in the planning and analysis of energy supply systems. An example of the increasing application of the AHP in energy system forecasting in general, and in the biofuel system in particular, is presented in Figure 2. In this case, authors have focused only on biofuel production 
because it is quite difficult to separate bioenergy-related analytical projects from other projects (bioenergy is involved in the majority of "general" energy-related AHP projects). Figure 2 summarizes a query on the number of articles in the Scopus document retrieval system. The keywords were "Analytic hierarchy process" AND energy in the first case, and in the second case, "Analytic hierarchy process" AND energy AND (biofuel* OR bioet* OR biocarb* OR biodies*) AND DOCTYPE (ar). The number of publications applying the AHP in the field of energy in general, and biofuel-related problems in particular, has grown exponentially since 2010 .

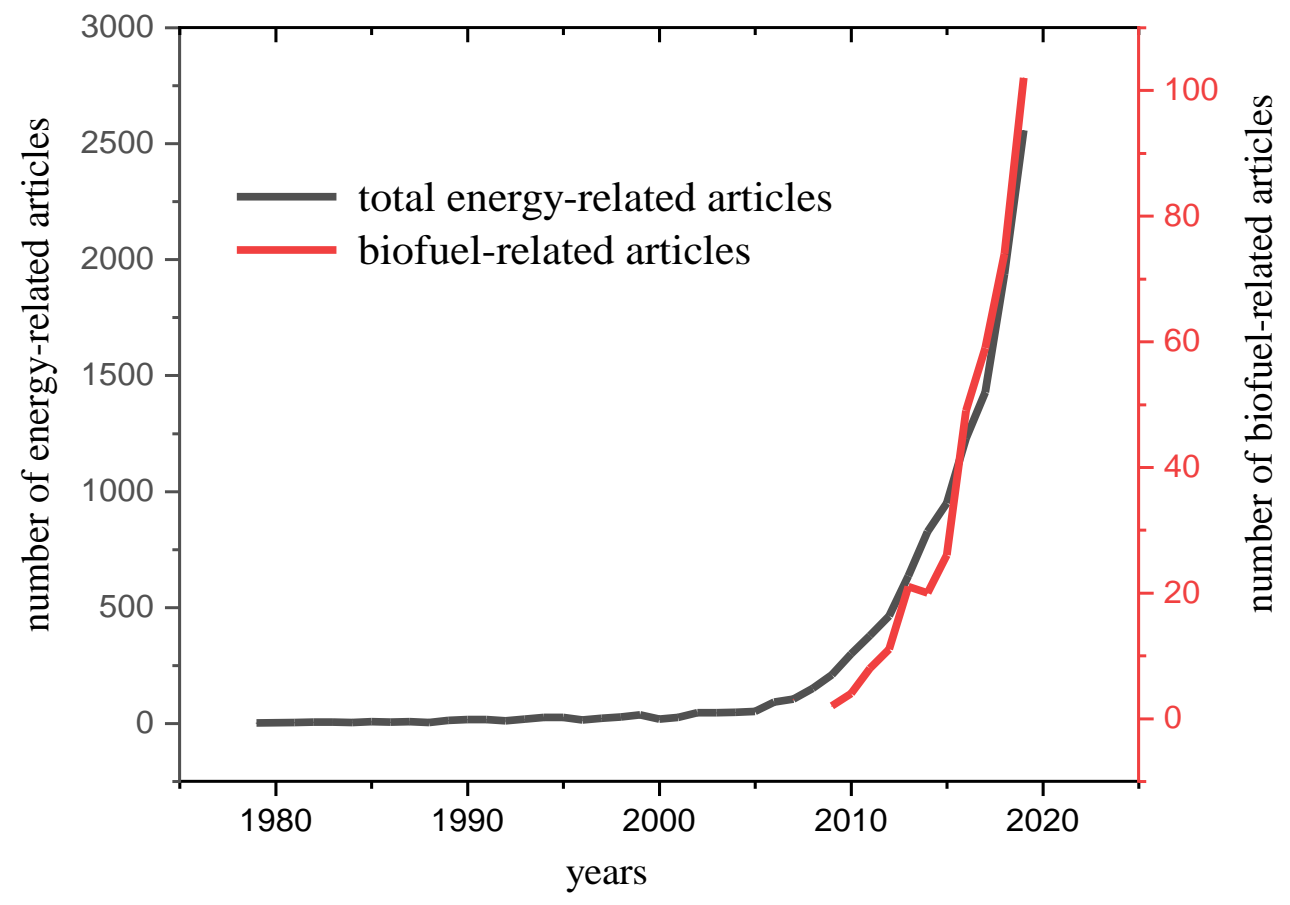

Figure 2. The number of articles applying the AHP to energy-related decision analysis in general, and to biofuel-related decision analysis in particular, based on Scopus.

The corpus of publications concerning the application of the AHP in the energy sector based on the WoS consists of 2004 items. This is a different dataset we searched first because the keywords were different. This set was divided into different clusters using CitNetExplorer software, and the AHP literature was analyzed using the same software. Based on the Leuven clustering method, five clusters were distinguished. The largest cluster has nearly 900 publications based on the work of Saaty [40]. The second largest cluster, with more than 420 publications, was developed by Zadeh [44], including the AHP with fuzzy sets theory. The third most important cluster contains roughly half of the number of publications in the second cluster. This group is based on the work of Goumas and Lygerou [45], combining the traditional PROMETHEE method with the fuzzy approach. In this group, the vast majority of articles focus on energy policy. The fourth cluster applies the AHP technique to optimize the geographical positioning of different projects. The fifth cluster is based on the application of the Delphi method.

The studies on the AHP show a relatively high level of concentration by country-i.e., the ten most important countries in the world produce AHP-related articles based on the home country of the corresponding authors. The most important countries are shown in Figure 3. 


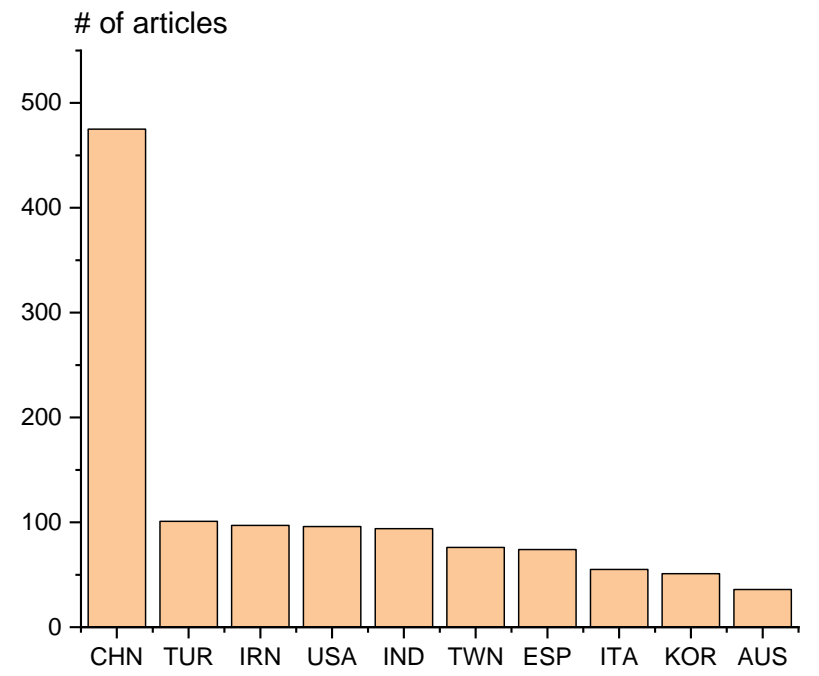

Figure 3. The key countries of AHP-related energy studies, based on the country of the corresponding author.

The majority of AHP studies related to energy concern China and other developed countries (Figure 3). Analysis of the energy sector in central European and Balkan states can be considered a lesser studied realm in the current situation; however, these countries can be characterized by numerous specific features: (1) a relatively low level of endowment of traditional energy resources (e.g., mineral oil); (2) a high level of energy dependence on Russia; (3) a lack of material resources for the rapid development or transformation of the energy sector; and, (4) due to the landlocked characteristic of numerous countries (the Czech Republic, Slovakia, Hungary, Serbia and North Macedonia), a rather limited access to alternative oil imports.

The results of the AHP analyses in the renewable energy sector are summarized in Table 2. In summary, it can be concluded that the focus of energy policy research is related to renewable energy. The AHP is gaining importance within energy policy research in general, and in renewable energy studies in particular.

Table 2. Results of AHP analyses of some renewable energy projects.

\begin{tabular}{lll}
\hline Xiaohua and Zhenmin [46] & & \\
\hline Sustainable energy supply & & 0.072 \\
& Energy supply for industry & 0.637 \\
& Energy supply for households & 0.258 \\
& Household energy availability rate & 0.105 \\
Sustainable energy consumption & 0.472 \\
& Energy benefit index & 0.484 \\
& Energy saving rate & 0.226 \\
& Energy efficiency & 0.064 \\
Energy exploitation & Community-based energy in total energy & 0.141 \\
& Annual electricity consumption & 0.149 \\
& & 0.170 \\
Environmental aspects & Satisfaction of energy demand & 0.750 \\
& Other renewable resources & 0.250 \\
& & 0.285 \\
& CO 2 discharging rate & 0.637 \\
& Organic matter in soil & 0.105 \\
& Forest cover & 0.258 \\
\hline
\end{tabular}


Table 2. Cont.

\begin{tabular}{|c|c|c|}
\hline \multicolumn{3}{|l|}{ Kurka [47] } \\
\hline Air quality & 0.173 & \\
\hline GHG emissions & 0.170 & \\
\hline Efficiency & 0.149 & \\
\hline Waste & 0.110 & \\
\hline Regional job creation & 0.099 & \\
\hline Regional food security & 0.098 & \\
\hline Economic viability & 0.091 & \\
\hline $\begin{array}{l}\text { Renewable energy } \\
\text { self-sufficiency }\end{array}$ & 0.062 & \\
\hline Technology & 0.048 & \\
\hline \multicolumn{3}{|l|}{ Yedla and Shrestha [48] } \\
\hline Energy efficiency & 0.147 & \\
\hline Emissions reduction & 0.132 & \\
\hline Economic feasibility & 0.139 & \\
\hline Technological preparedness & 0.207 & \\
\hline Adaptability & 0.219 & \\
\hline Barriers to implementation & 0.157 & \\
\hline \multicolumn{3}{|l|}{ Kaya and Kahraman [49] } \\
\hline Energy efficiency & 0.101 & \\
\hline Investment costs efficiency & 0.100 & \\
\hline Operation and maintenance & 0.113 & \\
\hline $\mathrm{NO}_{X}$ emissions & 0.128 & \\
\hline $\mathrm{CO}_{2}$ emissions & 0.152 & \\
\hline Land use & 0.109 & \\
\hline Social acceptability & 0.093 & \\
\hline Job creation & 0.123 & \\
\hline \multicolumn{3}{|l|}{ Yazdani-Chamzini et al. [50] } \\
\hline Power & 0.319 & \\
\hline Investment ratio & 0.090 & \\
\hline Implementation period & 0.026 & \\
\hline Operating hours & 0.116 & \\
\hline Useful life & 0.134 & \\
\hline $\begin{array}{l}\text { Operation and maintenance } \\
\text { costs }\end{array}$ & 0.042 & \\
\hline Tons of emissions avoided & 0.273 & \\
\hline \multicolumn{3}{|l|}{ Meixner [51] } \\
\hline Costs & 0.180 & \\
\hline Availability & 0.270 & \\
\hline Climate & 0.320 & \\
\hline Dependency & 0.050 & \\
\hline Utilization & 0.190 & \\
\hline \multicolumn{3}{|l|}{ Ahmad and Tahar [52] } \\
\hline \multirow[t]{4}{*}{ Technical } & & 0.265 \\
\hline & Maturity & 0.047 \\
\hline & Efficiency & 0.188 \\
\hline & Lead time & 0.020 \\
\hline \multirow[t]{5}{*}{ Economical } & & 0.520 \\
\hline & Costs & 0.231 \\
\hline & Operational lifetime & 0.054 \\
\hline & Resource protection & 0.122 \\
\hline & Decrease in tariff rate & 0.131 \\
\hline \multirow[t]{3}{*}{ Social } & & 0.0665 \\
\hline & Public acceptance & 0.017 \\
\hline & Workplace creation & 0.052 \\
\hline
\end{tabular}


Table 2. Cont.

\begin{tabular}{|c|c|c|}
\hline Environmental & $\begin{array}{l}\mathrm{CO}_{2} \text { reduction } \\
\text { Environmental impact } \\
\text { Land }\end{array}$ & $\begin{array}{l}0.1461 \\
0.093 \\
0.038 \\
0.015\end{array}$ \\
\hline
\end{tabular}

Source: Authors' own research.

\section{Methodology}

Synthesizing expert knowledge related to the topic of bioenergy requires an appropriate model and technique. The method selected was one of the well-proven techniques of Multi-Criteria Decision Making (MCDM), the analytic hierarchy process (AHP). Among the advantages of the AHP, the hierarchical structure of the decision elements, the consistency check and the clear interpretation of the results can be mentioned.

However, there are two types of bias attached to any AHP survey: a bias towards scoring in the pairwise comparisons (the AHP is based on a pairwise comparison of the hierarchical decision elements) and a bias towards deriving weights from the scoring, creating the risk that the determined weights (which are determined by the eigenvector method as the essence of the AHP) do not reflect the evaluators' real intentions.

In this paper, the first bias was handled on the one hand by a thorough explanation of the scoring procedure to the evaluators, and on the other hand by careful selection of the participants involved in the survey, who are well-known experts on the topic with relevant experience and knowledge of bioenergy. The second bias is connected to the weight derived from the scoring, which is a crucial phase of any AHP application as it produces the final results of the survey and completes the objective of the acquisition of knowledge. To ensure that the final results reflect the intentions of the decision makers, an extended model of the AHP was constructed: a Pareto AHP model. The Pareto approach is well known in the social sciences, and in this case, the AHP results are optimized from a Pareto point of view, i.e., the weight coordinates attached to decision elements cannot be improved in terms of the consistent approximation to the evaluator scores without worsening the approximation of other weight coordinates.

\subsection{The Analytic Hierarchy Process}

The analytic hierarchy process, originally created by Saaty [53], applies a strict hierarchical structure to the decision criteria of a complex, multi-level decision problem. The top level of the attributes refers to the most general criteria, while the lower levels contain more specific decision elements, and the last level is for the possible alternatives in the decision tree. The branches of this tree are also important as they determine not only the pairwise comparisons in the procedure but also the final weight and alternative scores by the reflection of the respective previous level element score.

Here, the method of the AHP is presented. Take an arbitrary complex decision problem, in which there are $n$ alternatives in the decision- $A_{1}, A_{2}, \ldots, A_{n}$-and $m$ criteria $-C_{1}, C_{2}, \ldots, C_{m}$. If we denote $\mathbf{A}^{(i)}$ as the pairwise comparison matrix of the alternatives with respect to the criterion $i$, then $w^{(i)}$, the weight vector, can be derived from the matrix $\mathbf{A}^{(i)}$ by Saaty's eigenvector method (the logarithmic least squares method can also be applied at this phase). Let us denote $\mathbf{C}$ as the pairwise comparison matrix of the criteria, and $w^{(c)}$ as the weight vector belonging to $\mathbf{C}$. Then, the final preference scores of the alternatives $u(w)$ can be calculated as follows:

$$
u w=w_{1}^{(C)} w^{1}+w_{2}^{(C)} w^{2}+\ldots+w_{m}^{(C)} w^{m}
$$

Saaty proved that for any PCM, the eigenvector belonging to the largest eigenvalue can be always computed for $\mathbf{C}$ and $\mathbf{A}^{(i)}$ by the following formula:

$$
\mathbf{A} w^{i}=\lambda_{\max } w^{i} .
$$


Then, the eigenvector $w$ can be gained as

$$
\left(\mathbf{A}-\lambda_{\max } \cdot \mathrm{I}\right) w^{i}=0,
$$

where $\lambda_{\max }$ is the largest eigenvalue of the matrix $\mathbf{A}$.

Consequently, the eigenvector is calculated as though the PCMs are consistent. The theoretical pairwise comparison matrices are always perfectly transitive (which means that if $a$ dominates $b$, and $b$ dominates $c$, then $a$ dominates $c$ among the matrix elements), but the matrices gained by surveys (evaluated by real people) are probably inconsistent to a certain extent.

Of course, the principal eigenvector of the consistent matrix exhibited in Table 3 is $\left\{w^{1} ; w^{2} ; \ldots ; w^{n}\right\}$ with the maximum eigenvalue of $\mathrm{n}$.

Table 3. The structure of a $(n \times n)$ perfectly consistent PCM.

\begin{tabular}{ccccc}
\hline$w^{1} / w^{1}$ & $\ldots$ & $\ldots$ & $\ldots$ & $w^{1} / w^{n}$ \\
\hline$\ldots$ & $\ldots$ & $\ldots$ & $\ldots$ & $\ldots$ \\
\hline$\ldots$ & $\ldots$ & $\ldots$ & $\ldots$ & $\ldots$ \\
\hline$w^{n} / w^{1}$ & $\ldots$ & $\ldots$ & $\ldots$ & $\ldots$ \\
\hline$w^{n} / w^{2}$ & $\ldots$ & $\ldots$ & $w^{n} / w^{n}$ \\
\hline
\end{tabular}

Source: Authors' own research.

In all AHP procedures, the respondents fill the created PCMs by providing their estimation on the relative importance/significance and scoring the brackets of the PCM above the main diagonal (due to the reciprocity, scoring other positions is redundant). In most cases, participants select values from the Saaty scale for the scoring (Table 4).

Table 4. Pairwise scale (1-9) of relative weight of criteria in PCMs [54].

\begin{tabular}{cc}
\hline Numerical Values & Verbal Scale \\
\hline 1 & Neutral connection of elements \\
2 & Slightly more significant \\
3 & Moderately more significant \\
4 & Moderately to strongly more significant \\
5 & Strong significance \\
6 & Strongly to very strongly significant \\
7 & Very strongly significant \\
8 & Very strongly to extremely significant \\
9 & Extreme significance of one element over another \\
\hline
\end{tabular}

Source: Authors' own research.

Even for the practical PCMs, the reciprocity $\left(a_{j i}=1 / a_{i j}\right.$, where $\left.a_{i i}=1\right)$ needs to be fulfilled; however, these practical matrices probably do not fulfil the condition of consistency. Thus, $a_{i k} \neq a_{i j} \cdot a_{j k}$.

Based on the above-presented features, the consistency of evaluators' ratings had to be measured in practical matrices of $\mathbf{C}$ and $\mathbf{A}^{(i)}$. Following Saaty's procedure, initially, the Random Index (RI) had to be determined by selecting the value of the same size PCM as presented (Table 2). The maximum number of attributes belonging to one branch of the decision tree in our decision problem was seven, so we presented the random index values for up to seven criteria (Table 5).

Table 5. The utilized Random Index (RI) values in the AHP.

\begin{tabular}{lllccccc}
\hline Number of Attributes & 1 & 2 & 3 & 4 & 5 & 6 & 7 \\
Random Index Values & 0 & 0 & 0.58 & 0.9 & 1.12 & 1.24 & 1.32 \\
\hline Source: Authors' own research & & &
\end{tabular}


Having gained all comparisons, the consistency index (CI) was computed by using formula (4).

$$
\mathrm{CI}=\left(\lambda_{\max }-n\right) /(n-1)
$$

where $\lambda_{\max }$ is the principal eigenvalue of the PCM and $n$ is the number of rows in the practical matrix.

After calculating the RI and CI values, the consistency ratio (CR) could be gained by

$$
\mathrm{CR}=\mathrm{CI} / \mathrm{RI}
$$

The CR is acceptably inconsistent when its value is less than $0.1[54,55]$.

Completing the sensitivity analysis is the last phase of the AHP procedure, which enables decision makers to check the robustness of the outcomes of the calculations by assessing the effect of small modifications of certain weight scores on the total decision structure priorities and ranking.

\subsection{The Concept of Pareto AHP}

Many researchers brought attention to the fact that in the AHP, the eigenvectors and the final scores of the criteria and alternatives are not always Pareto optimal; Bozóki and Fülöp [30] first described this phenomenon in the case of $4 \times 4$ and larger matrices. Therefore, $w^{i}$-s can be tested and improved with dominant weight vectors that give better approximation to $a_{i j}$-s than the eigenvectors do.

Let us have $\mathbf{A}$, a pair wise comparison matrix, $A=\left[a_{i j}\right]_{i, j=1, \ldots n} \in P C_{n}(P C M$ means the pairwise comparison matrix of AHP here) and $w=\left(w_{1}, w_{2}, w_{3}, \ldots w_{n}\right)^{\top}$ is a positive weight vector (for $S=\mathbb{R}_{++}^{n}$, is positive orthant), and $n$ is the number of criteria in the examined matrix. The objective function

$$
f_{i j}(w):=\left|a_{i j}-\frac{w_{i}}{w_{j}}\right| \quad \text { for all } \quad \mathrm{i} \neq \mathrm{j}, M=n^{2}-n
$$

and $M$ is the total number of the objective functions [56].

Based on that, functions can be created for minimizing the difference between each $a_{i j}$ and $\frac{w_{i}}{w_{j}}$ value.

$$
f_{i j}: \mathbb{R}_{++}^{n} \rightarrow \mathbb{R}, i, j=1, \ldots, n, \min \mathrm{f}(\mathrm{x})
$$

Bozóki and Fülöp [30] created an algorithm for solving this objective function with the appropriate constrains. In the current research, this algorithm has been applied for all $4 \times 4$ or larger matrices evaluated in the survey.

Both theoretical evidence from Bozóki and Fülöp [30] and real-world evidence from Duleba and Moslem [57] exist for possible rank reversal in the prioritization without conducting the so-called Pareto test on the AHP results. This Pareto test ensures that the order of the attributes is robust and cannot be further improved to get closer to the real intentions of the expert evaluators. In this study, we conducted the Pareto test in all relevant cases. There is only one other example of utilizing the Pareto test in the AHP by Duleba et al. [58], who conducted an expert survey on the vital factors of autonomous vehicle testing. In the field of bio-based energy systems, this approach can be considered unique and might contribute to future expert survey analyses in this domain.

\subsubsection{The Test Tube: Some Relevant Characteristic Features of Hungary}

Optimizing the energy portfolio of Hungary, a small, open economy, is an especially complex problem because the country has numerous specific features. The most important characteristic features of the country in the context of its energy policy are as follows:

(1) A high level of openness, the importance of foreign trade and a highly diversified export structure. In terms of economic complexity, this is the tenth most diversified economy in the world according to Ertan Özgüzer and Oğuş-Binatlı [59]. The top 
exports of Hungary are cars, info-communication technology products and electric equipment [60].

(2) The natural energy resources are rather limited: there are neither oil nor gas deposits according to Bluszcz [61], nor such hydrogeological conditions that could be useful for hydroelectric power generation [62]. The coal deposits are limited and of low quality.

(3) Due to the meteorological conditions, the possibilities of wind energy are much more limited than, for example, in Germany (Németh et al. [63]).

(4) In spite of the low level of natural endowment of energy resources, the country has considerable possibilities for agricultural production [64]. The per capita arable land endowment is ca. $0.5 \mathrm{ha}$, which is one of the highest in Europe.

(5) Another important resource is tourism, based on thermal waters and Lake Balaton (the largest lake in central Europe) and rural tourism offering favorable possibilities for development [65].

(6) One of the most important parts of the Hungarian energy sector is nuclear energy, and considerable efforts have been made by the Hungarian government to enhance the nuclear energy generation capacity. However, analysis of the potential conflict between atomic energy and renewables would go beyond the limits of the current work due to its extremely high level of complexity [66]. In addition, this topic is well studied in the literature [67].

\subsubsection{The Procedure}

In the first phase of the research, a catalogue of potential respondents was set up based on three partially overlapping criteria: (a) a well-documented presence of agricultural policy, energy policy, economic strategy and rural development in academic debates; (b) a position in policy making and regional decision making; and (c) personal experience in the field of practical realization of energy policy. The structure and basic socio-economic characteristics of the respondents are summarized in Table 6.

Table 6. Basic socio-economic characteristics of the respondents.

\begin{tabular}{lc}
\hline Highest Level of Qualification (\%) & \\
\hline MSc & $65 \%$ \\
PhD & $35 \%$ \\
Average length of professional experience (years) & 14.3 \\
Scope of activity (\%) & 86 \\
Higher education and research & 10 \\
Agricultural production & 4 \\
Mineral oil production, processing and trade & \\
Gender (\%) & 43 \\
Women & 57 \\
\hline
\end{tabular}

Source: Authors' own research.

The pool of respondents consisted of specialists with an MSc or PhD qualification. Currently, the Hungarian governmental system is heavily influenced by party politics and ideology according to Vegetti [68]; therefore, the involvement of government-level political decision makers directly influenced by political ideologies was excluded. Finally, emphasis was put on the regional development experience of university specialists. In summary, it can be concluded that, taking into consideration the relatively small pool of potential respondents based on Hungary's size and bioenergy sector, the number and professional backgrounds of respondents are a good representation of a rather wide range of independent specialists in the field of bioenergy.

The questionnaires were based on in-depth interviews with potential stakeholders and on the academic literature, using natural language processing to extract the most important and relevant statements. The form of the questionnaires followed the general procedure and the AHP evaluation of questionnaires was as described in detail in the 
literature [54]. Based on the literature search strategy, described in detail in Section 2.2, we conducted a previous scoping review to obtain a general picture of the main direction and problems of bioenergy project development. Based on this, we set up a long list of statements, consisting of 135 items. These were hierarchically ordered in a framework of three workshops. In each workshop, the number of participants was between 7 and 12. In this process, we used simple visualization methods, such as interactive electronic tables. The hierarchy of items was established by consensus.

Although the questionnaire did not feature any sensitive, personal information, we consulted the Ethical Council of the University of Debrecen, which did not raise any concerns regarding the method, format or content of the research.

\section{Results and Discussion}

All the results presented in this section were verified by the Pareto test of the analytic hierarchy process; thus, the ranks and scores can be considered robust. For all groups of attributes containing four or more aspect/function members, Pareto optimality has been checked and proven.

In the presented case study, we utilized three hierarchical levels containing 52 attributes/criteria in total. On the first level, merely three general criteria were positioned. On the second level, nine criteria were present, while on the third level, there were 40. Based on the designed structure, we had a $3 \times 3$ pairwise comparison matrix on the first level; three $3 \times 3$-sized matrices on the second; and four $3 \times 3$, one $4 \times 4$, two $5 \times 5$ and two $7 \times 7$ matrices on the third. Consequently, by the survey and the eigenvector computation (note that we applied the AIJ technique of AHP, so first, the individual matrices were aggregated to one global matrix), altogether, we gained eight three-dimensional weight vectors (from the $3 \times 3$-sized matrices), one four-dimensional weight vector, two five-dimensional vectors and two seven-dimensional vectors. Following the Pareto test guidance and the theoretical findings that non-optimality might only occur in case of $4 \times 4$ or larger matrices, we examined five weight vectors from the Pareto aspect (a four-dimensional, two five-dimensional and two seven-dimensional vectors). The result of the four-dimensional vector is presented in Table 7.

Table 7. The Pareto test on the four-dimensional weight vector of the decision attributes.

\begin{tabular}{ccc}
\hline Original Weight Vector & Pareto Optimal Vector & Difference \\
\hline 0.4305 & 0.4305 & 0 \\
\hline 0.3185 & 0.3185 & 0 \\
\hline 0.1368 & 0.1368 & 0 \\
\hline 0.1142 & 0.1142 & 0 \\
\hline
\end{tabular}

In all four cases, the Pareto optimal vector was identical to the weight vector computed from the survey scores; thus, the results can be considered robust. Considering that we only examined the values up to four digits, a more sophisticated test could possibly have indicated slight differences between the original weight vector and the Pareto optimal vector; however, it must be outlined that in this case, the difference is non-significant from the aspect of the case study.

It is possible that due to the high level of competence of the experts in the evaluation process, all scorings were verified as Pareto optimal; consequently, the final outcomes are trustworthy and unbiased.

There is a wide-ranging consensus that different projects should be evaluated on the basis of their economic, social and environmental impacts $[69,70]$. In the first phase, the relative importance of these three domains of bioenergy projects was analyzed. The results of this phase of the research are summarized in Table 8. 
Table 8. Results of the AHP on weighting the relative importance of three dimensions of bioenergy projects.

\begin{tabular}{ll}
\hline Aspect/Function & Relative Weight \\
\hline Economic functions & 0.4731 \\
Environmental functions & 0.3778 \\
Social functions & 0.1489 \\
\hline Source: Authors' own research.
\end{tabular}

In the opinion of the respondents, the most important function of bioenergy is its contribution to the development of the economy. This fact could be explained by two factors: (1) the relative level of economic development is lower in Hungary than in the more developed western European countries, and there is a high level of motivation to catch up in a relatively short time to the more economically advanced countries; (2) in the value system of central European citizens, the importance of environmental functions is still relatively low [71].

The significance of the social function in bioenergy projects was especially low in Hungary, which is in contradiction with the results of AHP studies conducted outside of Hungary. Therefore, it seems to be a good idea to further analyze the partial influence of different sub-factors.

\subsection{Economic Factors and Consequences of Bioenergy Projects}

By analyzing the economic functions of bioenergy projects, it becomes clear that adequate income is a key driver of economic development, since the generation of income and value added is relatively low in Hungarian agriculture (Table 9). Currently, the subsidies of the Common Agricultural Policy of the EU, acting as a "ventilator", are able to counterbalance the low level of efficiency, but reformation of the EU budget could jeopardize the income stability of farms [72].

Table 9. Results of the AHP on weighting the relative importance of the economic dimensions of bioenergy projects.

\begin{tabular}{ll}
\hline Aspect/Function & Relative Weight \\
\hline Upgrading the income-generating capacity of farms & 0.4118 \\
Reducing the utilization of fossil fuels & 0.4501 \\
Possibilities of utilization of by-products of bioenergy projects & 0.1382 \\
\hline Source: Authors' own research. &
\end{tabular}

In Hungary, energy dependence on oil and natural gas is especially high accounting for $80 \%$. At the same time, the declining share of fossil fuels in electricity production can be observed due to the increasing use of renewable energy sources; however, the greatest proportion of electricity is generated from nuclear power. The reducing fossil fuel use can be explained by two main factors: a general increase in the awareness that fossil fuels are harmful to the environment, and the desire to reduce the reliance on limited fossil fuels.

Analyzing the system of sub-criteria within the economic dimension, a higher weight was attached to the criterion of reducing dependence on energy imports (Table 10). This can be explained by the general global tendency towards increasing energy sovereignty and by the negative consequences of the Russian-Ukrainian conflict on Hungary's energy supply system, as it jeopardized the stability of Ukrainian energy transit [73]. Stabilization between the supply and demand of agricultural products is a considerable problem in the EU. On the one hand, the diversification of land use (e.g., energy crop production) could contribute to a decreasing supply of food products, leading to increasing food prices. On the other hand, the competitiveness between the food and biofuels industries for the same crops may enhance farm incomes. In summary, the experts assigned importance to biofuel production due to decreasing energy dependence and increasing farm incomes. Interestingly, the diversification of agricultural production was given a relatively low value. 
Table 10. Relative importance of different sub-criteria ordered by ascending rank order of sub-criteria.

\begin{tabular}{llll}
\hline Function/Goal & Normalized Weights & Finalized Weights & Rank \\
\hline Reducing dependence on imports of energy resources & 0.3554 & 0.0756 & 1 \\
$\begin{array}{l}\text { Diversion of utilization of agricultural production potential } \\
\text { Replacement of fossil energy resources }\end{array}$ & 0.2622 & 0.0511 & 0.0494 \\
$\begin{array}{l}\text { Stabilization of agricultural markets } \\
\text { Reducing dependence on foreign oil }\end{array}$ & 0.2322 & 0.2353 & 0.04587 \\
$\begin{array}{l}\text { Utilization of by-products of bioenergy projects (e.g., dried } \\
\text { distillery grain with solubles, corn gluten feed, corn gluten }\end{array}$ & 0.2147 & 0.6056 & 0.0395 \\
$\begin{array}{l}\text { meal in the case of bioethanol projects) } \\
\text { Stabilization of producers' incomes }\end{array}$ & 0.1801 & 0.0351 \\
$\begin{array}{l}\text { Diversification of the energy portfolio } \\
\text { Creation of a network for raw material suppliers }\end{array}$ & 0.1481 & 0.0315 \\
$\begin{array}{l}\text { Increasing value added of agricultural products by processing } \\
\text { Reducing import dependence on protein feed (by-products of }\end{array}$ & 0.1046 & 0.0203 & 7 \\
bioethanol production) & 0.2778 & 0.0190 \\
$\begin{array}{l}\text { Motivation of the optimal utilization of land by increasing land } \\
\text { usage alternatives }\end{array}$ & 0.0724 & 0.0181 \\
$\begin{array}{l}\text { Reducing fossil energy resource prices by increasing and } \\
\text { diversifying the energy supply }\end{array}$ & 0.0493 & 0.0141 \\
$\begin{array}{l}\text { Contribution to the increase in agricultural raw material prices } \\
\text { Production of environmentally friendly food or food products }\end{array}$ & 0.0475 & 0.1164 & 0.0105 \\
\hline
\end{tabular}

Source: Authors' own research.

\subsection{Environmental Criteria of Bioenergy Production}

The most important environmental aspect of bioenergy projects was considered to be the contribution made to environmental protection, followed by the contribution made to saving the rural landscape (Table 11). The results are in line with the opinion of [74], who highlighted that environmental problems are not yet at the center of political discussions. At first, this might seem surprising, but we have to take into consideration that the traditional Hungarian landscape is an important part of the national identity [75]. Howley [76] has proven that landscape is an important carrier of aesthetic value, but there are considerable individual differences in the preference structure.

Table 11. Results of the AHP on weighting the relative importance of the environmental dimension of bioenergy projects.

\begin{tabular}{cc}
\hline Aspect/Function & Relative Weight \\
\hline Contribution to saving the rural landscape & 0.3244 \\
Contribution to environmental protection & 0.4717 \\
Improvement of harmony between society and nature & 0.2038 \\
\hline
\end{tabular}

Source: Authors' own research.

The improvement of harmony between the development of the economy and society is a generally accepted goal, but one that is difficult to achieve. Bioenergy projects should contribute to improvements in life quality and to the promotion of better harmony between citizens, society and the economy. These could be quantified by different indices (e.g., the Human Development Index Streimikiene [77], Sagar and Najam [78], the Sustainable Economic Welfare Index, the Genuine Progress Indicator, Lawn [79], etc.).

In line with the general results, the sub-criterion of reducing $\mathrm{CO}_{2}$ emissions and other greenhouse gases received the highest relative importance (Table 12). This fact can be interpreted by the increasing perception of the negative consequences of the economic burden on local (e.g., health-related) and global (e.g., greenhouse gas emissions) problems [80-82]. The results of the survey highlight the dominant paradigm of the last 30 years according to Weinschenck [83], which has been that the cheapest way of safeguarding the agricultural landscape is rational agricultural production. 
Table 12. The relative importance of different environment-related sub-criteria, ordered by the ascending rank order of sub-criteria.

\begin{tabular}{|c|c|c|c|}
\hline Sub-Criteria & Normalized Weights & Finalized Weights & Rank \\
\hline Reducing $\mathrm{CO}_{2}$ emissions and other greenhouse gases & 0.6425 & 0.1145 & 2 \\
\hline Maintenance of natural and landscape values and their diversity & 0.6105 & 0.0748 & 3 \\
\hline Improvement in the Human Development Index (HDI) & 0.5200 & 0.0400 & 8 \\
\hline Diversification of agricultural production & 0.2605 & 0.0319 & 12 \\
\hline Reducing the ecological footprint of production & 0.1409 & 0.0251 & 14 \\
\hline Improving the Index of Sustainable Economic Welfare (ISEW) & 0.2937 & 0.0226 & 16 \\
\hline Contributing to the solution of global environmental problems & 0.1136 & 0.0202 & 20 \\
\hline Safeguarding the biosphere & 0.1029 & 0.0183 & 22 \\
\hline $\begin{array}{l}\text { Protecting natural resources by maintaining the agricultural } \\
\text { culture-landscape }\end{array}$ & 0.1289 & 0.0158 & 24 \\
\hline
\end{tabular}

Source: Authors' own research.

\subsection{The Role of Projects in Regional Development}

The most important social function of energy policies is the enhancement of rural occupations and the quality of rural life. The workplace creation effect of modern, industrial bioenergy projects is rather marginal. Among the economic aspects of bioenergy production, priority was given to increasing farm income. At the same time, the utilization of by-products (e.g., in the case of bioethanol production) also obtained a high importance (Table 13).

Table 13. Results of the AHP on weighting the relative importance of the economic dimensions of bioenergy projects.

\begin{tabular}{cc}
\hline Aspect/Function & Relative Weight \\
\hline Increasing the income of farms & 0.41187 \\
Reducing the use of fossil fuels & 0.45000 \\
Utilization of by-products (bioethanol) & 0.13811 \\
\hline
\end{tabular}

Source: Authors' own research.

The role of bioenergy projects as rural innovations based on their social functions (Table 14) can be analyzed in terms of three pillars: increasing rural workplaces and improving the quality of life; contributing to the preservation of the cultural heritage; and improving the human resource capacity in rural regions. When analyzing the local importance of bioenergy projects, the respondents attached an importance value of 0.13 to increasing employment. At first, this is surprising, because in central and eastern Europe, there is a great need for projects that contribute to regional development $[67,84]$. This contradiction may be based on the perception that modern bioenergy systems are not considered to be important drivers for creating workplaces. Despite numerous references to creating workplaces in the bioenergy sectors by Mironenko and Poleva [85] and Luca et al. [84], highlighting the importance of bioenergy projects in rural development by Igliński et al. [86], there are no documented arguments supporting the effects of these projects on increasing competitiveness and the quality of life in central and eastern Europe.

Analyzing the differences in the opinions of the specialists according to their professional activity, it can be concluded that experts working directly in agriculture had an above-average preference towards increasing farm incomes based on bioenergy projects. Experts working in the fossil energy sector gave an above-average importance to energy independence. 
Table 14. Relative importance of social dimension components.

\begin{tabular}{|c|c|c|c|}
\hline Sub-Criteria & Normalized Weights & Finalized Weights & Rank \\
\hline Creating workplaces & 0.3064 & 0.0209 & 18 \\
\hline Reducing workforce mobility & 0.1849 & 0.0126 & 28 \\
\hline Strengthening the socio-economic position of family enterprises & 0.1699 & 0.0116 & 29 \\
\hline Increasing the activity of rural communities & 0.1239 & 0.0084 & 33 \\
\hline Contributing to the social responsibility of economic stakeholders & 0.0848 & 0.0057 & 35 \\
\hline Strengthening social capital in rural regions & 0.0714 & 0.0048 & 37 \\
\hline $\begin{array}{l}\text { Promoting the public transport system by enhancing } \\
\text { environmentally friendly solutions }\end{array}$ & 0.0583 & 0.0039 & 39 \\
\hline Maintaining traditional architecture & 0.5845 & 0.0215 & 17 \\
\hline Enhancing the knowledge base in rural regions & 0.2903 & 0.0107 & 30 \\
\hline Enhancing bioenergy-specific knowledge in rural regions & 0.1250 & 0.0046 & 38 \\
\hline Enhancing special education & 0.5631 & 0.0246 & 15 \\
\hline Promoting cluster formation in bioenergy-related fields & 0.3185 & 0.0139 & 27 \\
\hline Giving new impetus to research, development and innovation & 0.1182 & 0.0051 & 36 \\
\hline
\end{tabular}

Source: Authors' own research.

\section{Discussion and Conclusions}

The results have shown that when evaluating the most important aspects of bioenergybased projects, Hungarian experts attach relatively high importance to economic factors, as opposed to the conclusions reached by the European and Chinese scientists Xiaohua and Zhenmin [46], Kurka [47] and Meixner [51], who placed approximately similar importance on economic, environmental and regional considerations. This contradiction can be explained by the fact that the income-generating capacity of Hungarian agriculture is rather low, and the main driver of its development is the financial transfer in the framework of the Common Agricultural Policy of the European Union [87].

This can be explained by the relatively low farm income in Hungary.

Although it is rather difficult to define policy guidelines in an unstable regulatory environment, four pillars should be highlighted:

1. Bioenergy projects ensure a sustainable intensification in agricultural production. This is an extremely important precondition of environmental management because rational agricultural production is the cheapest and most suitable way to protect the environment and safeguard the natural landscape [83].

2. Bioenergy should be considered a source of national energy independence, as a decreasing dependence on energy can be achieved [88].

3. Central and eastern European countries are situated in regions where the future consequences of global climate change are rather hard to predict, as opposed, for example, to Kazakhstan, where there are numerous signs of increasing agricultural potential [89]. It is possible that the years to come will be characterized by extremely low yields due to decreasing precipitation and increasing temperature in the vegetation period [90].

4. By-products of bioethanol production can be used as protein feed in the livestock sector according to Arodudu et al. [91], but the rapid reduction in animal production in Hungary forces biofuel producers to export by-products all over the world.

The most important aim of this research was to map the evaluation and value systems of experts. In the future, a comprehensive bioeconomy strategy could be formulated in line with current documents of the European Union and some of its member states. An important part of this bioeconomy strategy could be the determination of the place and role of bioenergy [92].

However, the limits of our current knowledge must also be recognized. These biases can be divided into two aspects:

1. Firstly, the bioenergy policy of the EU is a rather confused one, creating a high level of uncertainty [93]. Given the lack of coherence, bioenergy projects are subject to the individual decisions of member states [94]. In the case of a small country with rela- 
tively under-developed political control mechanisms and a lack of counterbalances, as highlighted by Sata and Karolewski [95], bioenergy-related decisions depend on the level of influence of stakeholder lobbies and the influence of other member states of the EU.

2. Notwithstanding the considerable increase in the number of publications, there are numerous questions to which no definitive response can be given based on evidence and a wide-ranging consensus among the academic community. These can be divided into two categories:

(a) A lack of evidence regarding the environmental and health-related aspects of bioenergy projects. There is a widespread hypothesis on the favorable environmental and health aspects of bioenergy projects underlined by Banimostafa et al. [96] and Kheybari et al. [97], although there is no wide-ranging evidence on the positive effects of bioenergy projects on human health via an improvement in air quality [98].

(b) There are considerable differences among countries in terms of agricultural technologies and the cost-benefit relationship. The results of a life-cycle analysis are not directly transferable from one macro-region to another; thus, a complex life-cycle-based analysis focused on specific conditions is essential.

The limitation of the study results from the method applied. The AHP is based mainly on a comparative analysis of imponderables and the tacit knowledge of experts. Even if by applying the amended form of the method with the Pareto optimality aspect, the bias of the responses could be mitigated and the robustness of the ranking ensured, the results can be considered a synthesis of opinions rather than an objective final prioritization, despite the fact that the limited number of respondents did not provide a great deal of variance among their evaluations of the different aspects of bioenergy projects. From this, it follows that increasing the number of respondents would not significantly enhance the reliability of the research. However, the application of more "hard" methods, above all system dynamic modeling, would be an important step towards reaching a better understanding of the socio-economic mechanisms determined by bioenergy systems.

Author Contributions: J.O.: writing-original draft, conceptualization and data curation. Z.L.: writing-original draft, data curation and visualization. S.D.: methodology and investigation. J.P. and A.K.: writing-review and editing, formal analysis. All authors have read and agreed to the published version of the manuscript.

Funding: Project no. 132,805 was implemented with support provided from the National Research, Development, and Innovation Fund of Hungary, financed under the K_19 funding scheme and supported by the János Bolyai Research Scholarship of the Hungarian Academy of Sciences (BO/00095/18 and $\mathrm{BO} / 8 / 20)$.

Institutional Review Board Statement: The study was conducted according to the guidelines of the Declaration of Helsinki, and approved by the Institutional Review Board (or Ethics Committee) of University of Debrecen (https:/ / unideb.hu/hu/etikai-bizottsag accessed on 6 April 2021).

Data Availability Statement: Data on survey can be obtained from the corresponding author upon request.

Acknowledgments: Project no. 132,805 was implemented with support provided from the National Research, Development, and Innovation Fund of Hungary, financed under the K_19 funding scheme and supported by the János Bolyai Research Scholarship of the Hungarian Academy of Sciences (BO/00095/18 and $\mathrm{BO} / 8 / 20)$.

Conflicts of Interest: The authors declare no conflict of interest.

Declaration of Competing Interest: The authors declare that they have no known competing financial interest or personal relationships that could have appeared to influence the work reported in this paper. 


\section{References}

1. Gruia, R. "Human being-environment" system as hypercomplex system. J. EcoAgriTourism 2009, 5, 7-14. Available online: https:/ / www.cabdirect.org/cabdirect/abstract/20113032270 (accessed on 6 April 2021).

2. Herrmann-Pillath, C. The art of co-creation: An intervention in the philosophy of ecological economics. Ecol. Econ. 2020, 169, 106526. [CrossRef]

3. Christophers, B. Environmental beta or how institutional investors think about climate change and fossil fuel risk. Ann. Am. Assoc. Geogr. 2019, 109, 754-774. [CrossRef]

4. Galaz, V.; Crona, B.; Dauriach, A.; Scholtens, B.; Steffen, W. Finance and the Earth system-Exploring the links between financial actors and non-linear changes in the climate system. Glob. Environ. Chang. Hum. Policy Dimens. 2018, 53, 296-302. [CrossRef]

5. Knutti, R.; Rugenstein, M.A. Feedbacks, climate sensitivity and the limits of linear models. Philos. Trans. R. Soc. A Math. Phys. Eng. Sci. 2015, 373, 20150146. [CrossRef]

6. Gilley, B. Technocracy and democracy as spheres of justice in public policy. Policy Sci. 2017, 50, 9-22. [CrossRef]

7. Jones, B.R.; Sovacool, B.K.; Sidortsov, R.V. Making the ethical and philosophical case for "energy justice". Environmental. Ethics 2015, 37, 145-168. [CrossRef]

8. Sovacool, B.K.; Brown, M.A. Conclusions-Replacing Myths With Maxims: Rethinking The Relationship Between Energy And American Society. In Energy and American Society-Thirteen Myths; Springer: Dordrecht, The Netherlands, 2007; pp. 351-366.

9. Sovacool, B.K.; Burke, M.; Baker, L.; Kotikalapudi, C.K.; Wlokas, H. New frontiers and conceptual frameworks for energy justice. Energy Policy 2017, 105, 677-691. [CrossRef]

10. Nerini, F.F.; Tomei, J.; To, L.S.; Bisaga, I.; Parikh, P.; Black, M.; Borrion, A.; Spataru, C.; Broto, V.C.; Anandarajah, G.; et al. Mapping synergies and trade-offs between energy and the Sustainable Development Goals. Nat. Energy 2018, 3, 10-15. [CrossRef]

11. Mohr, L.; Burg, V.; Thees, O.; Trutnevyte, E. Spatial hot spots and clusters of bioenergy combined with socio-economic analysis in Switzerland. Renew. Energy 2019, 140, 840-851. [CrossRef]

12. Sharma, N.; Bohra, B.; Pragya, N.; Ciannella, R.; Dobie, P.; Lehmann, S. Bioenergy from agroforestry can lead to improved food security, climate change, soil quality, and rural development. Food Energy Secur. 2016, 5, 165-183. [CrossRef]

13. Sarkodie, S.A.; Strezov, V.; Weldekidan, H.; Asamoah, E.F.; Owusu, P.A.; Doyi, I.N.Y. Environmental sustainability assessment using dynamic autoregressive-distributed lag simulations-nexus between greenhouse gas emissions, biomass energy, food and economic growth. Sci. Total Environ. 2019, 668, 318-332. [CrossRef]

14. Sydney, E.B.; Letti, L.A.J.; Karp, S.G.; Sydney, A.C.N.; de Souza Vandenberghe, L.P.; de Carvalho, J.C.; Woiciechowski, A.L.; Medeiros, A.B.P.; Soccol, V.T.; Soccol, C.R. Current analysis and future perspective of reduction in worldwide greenhouse gases emissions by using first and second generation bioethanol in the transportation sector. Bioresour. Technol. Rep. 2019, 7, 100234. [CrossRef]

15. Nepal, S.; Tran, L.T. Identifying trade-offs between socio-economic and environmental factors for bioenergy crop production: A case study from northern Kentucky. Renew. Energy 2019, 142, 272-283. [CrossRef]

16. Allen, P.E.; Hammond, G.P. Bioenergy utilization for a low carbon future in the UK: The evaluation of some alternative scenarios and projections. BMC Energy 2019, 1, 3. [CrossRef]

17. Keček, D.; Mikulić, D.; Lovrinčević, Ž. Deployment of renewable energy: Economic effects on the Croatian economy. Energy Policy 2019, 126, 402-410. [CrossRef]

18. Jenssen, T.; König, A.; Eltrop, L. Bioenergy villages in Germany: Bringing a low carbon energy supply for rural areas into practice. Renew. Energy 2014, 61, 74-80. [CrossRef]

19. Berg, S.; Cloutier, L.; Bröring, S. Collective stakeholder representations and perceptions of drivers of novel biomass-based value chains. J. Clean Prod. 2018, 200, 231-241. [CrossRef]

20. Lijó, L.; González-García, S.; Lovarelli, D.; Moreira, M.T.; Feijoo, G.; Bacenetti, J. Life cycle assessment of renewable energy production from biomass. In Life Cycle Assessment of Energy Systems and Sustainable Energy Technologies; Springer: Berlin/Heidelberg, Germany, 2019; pp. 81-98.

21. Brandão, M.; Kirschbaum, M.U.; Cowie, A.L.; Hjuler, S.V. Quantifying the climate change effects of bioenergy systems: Comparison of 15 impact assessment methods. Glob. Chang. Biol. Bioenergy 2019, 11, 727-743. [CrossRef]

22. Kissinger, G.; Herold, M.; De Sy, V. Drivers of Deforestation and Forest Degradation: A Synthesis Report for REDD+ Policymakers; Citeseer: Old Main, PA, USA, 2012.

23. Burns, C.; Higson, A.; Hodgson, E. Five recommendations to kick-start bioeconomy innovation in the UK. Biofuel Bioprod Biorefin 2016, 10, 12-16. [CrossRef]

24. Cîrstea, S..D.; Cîrstea, A.; Popa, I.E.; Radu, G. The Role of Bioenergy in Transition to a Sustainable Bioeconomy-Study on EU Countries. Amfiteatru Econ. 2019, 21, 75-89. [CrossRef]

25. Popp, J.; Kovács, S.; Oláh, J.; Divéki, Z.; Balázs, E. Bioeconomy: Biomass and biomass-based energy supply and demand. N. Biotechnol. 2020, 60, 76-84. [CrossRef]

26. Wang, J.; Yang, Y.; Bentley, Y.; Geng, X.; Liu, X. Sustainability assessment of bioenergy from a global perspective: A review. Sustainability 2018, 10, 2739. [CrossRef]

27. Aghbashlo, M.; Khounani, Z.; Hosseinzadeh-Bandbafha, H.; Gupta, V.K.; Amiri, H.; Lam, S.S.; Morosuk, T.; Tabatabaei, M. Exergoenvironmental analysis of bioenergy systems: A comprehensive review. Renew. Sustain. Energy Rev. 2021, 149, 111399. [CrossRef] 
28. Elia, G.; Margherita, A. Can we solve wicked problems? A conceptual framework and a collective intelligence system to support problem analysis and solution design for complex social issues. Technol. Forecast. Soc. Chang. 2018, 133, 279-286. [CrossRef]

29. De Liddo, A. Making decision in open communities: Collective actions in the public realm. Group Decis. Negot. 2017, 26, 847-856. [CrossRef]

30. Bozóki, S.; Fülöp, J. Efficient weight vectors from pairwise comparison matrices. Eur. J. Oper. Res. 2018, 264, 419-427. [CrossRef]

31. Martín-Martín, A.; Orduna-Malea, E.; Thelwall, M.; López-Cózar, E.D. Google Scholar, Web of Science, and Scopus: A systematic comparison of citations in 252 subject categories. J. Inf. 2018, 12, 1160-1177. [CrossRef]

32. Visser, M.; van Eck, N.J.; Waltman, L. Large-scale comparison of bibliographic data sources: Scopus, Web of Science, Dimensions, Crossref, and Microsoft Academic. arXiv 2020, arXiv:2005.10732.

33. Cobo, M.J.; López-Herrera, A.G.; Herrera-Viedma, E.; Herrera, F. An approach for detecting, quantifying, and visualizing the evolution of a research field: A practical application to the fuzzy sets theory field. J. Inf. 2011, 5, 146-166. [CrossRef]

34. Hines, J.; Ebeling, A.; Barnes, A.D.; Brose, U.; Scherber, C.; Scheu, S.; Tscharntke, T.; Weisser, W.W.; Giling, D.P.; Klein, A.M.; et al. Mapping change in biodiversity and ecosystem function research: Food webs foster integration of experiments and science policy. In Advances in Ecological Research; Elsevier: Amsterdam, The Netherlands, 2019; Volume 61, pp. $297-322$.

35. Aslani, A.; Mazzuca-Sobczuk, T.; Eivazi, S.; Bekhrad, K. Analysis of bioenergy technologies development based on life cycle and adaptation trends. Renew. Energy 2018, 127, 1076-1086. [CrossRef]

36. Feinerer, I. Introduction to the tm Package Text Mining in R. 2013. Available online: http:/ / cran.r-project.org/web/packages/ tm/vignettes/tm.pdf (accessed on 6 April 2021).

37. Lin, B.; Sun, C. Evaluating carbon dioxide emissions in international trade of China. Energy Policy 2010, 38, 613-621. [CrossRef]

38. Hjørland, B. Evidence-based practice: An analysis based on the philosophy of science. J. Am. Soc. Inf. Sci. Technol. 2011, 62, 1301-1310. [CrossRef]

39. Bock, D. A Brief History of Item Theory. Educ. Meas. 1997, 16, 21-33. Available online: http:// citeseerx.ist.psu.edu/viewdoc/ download?doi=10.1.1.465.5140\&rep=rep1\&type=pdf (accessed on 6 April 2021). [CrossRef]

40. Saaty, T.L. The Analytic Hierarchy Process: Planning, Priority Setting, Resource Allocation, McGraw-Hill; McGraw-Hill International Book Co.: New York, NY, USA; London, UK, 1980; ISBN 978-0070543713.

41. Saaty, T.L. Decision making with the analytic hierarchy process. Int. J. Serv. Sci. 2008, 1, 83-98. [CrossRef]

42. Forman, E.; Peniwati, K. Aggregating individual judgments and priorities with the analytic hierarchy process. Eur. J. Oper. Res. 1998, 108, 165-169. [CrossRef]

43. Emrouznejad, A.; Marra, M. The state of the art development of AHP (1979-2017): A literature review with a social network analysis. Int. J. Prod. Res. 2017, 55, 6653-6675. [CrossRef]

44. Zadeh, L.A. Fuzzy sets. Inf. Control 1965, 8, 338-353. [CrossRef]

45. Goumas, M.; Lygerou, V. An extension of the PROMETHEE method for decision making in fuzzy environment: Ranking of alternative energy exploitation projects. Eur. J. Oper. Res. 2000, 123, 606-613. [CrossRef]

46. Xiaohua, W.; Zhenmin, F. Sustainable development of rural energy and its appraising system in China. Renew. Sustain. Energy Rev. 2002, 6, 395-404. [CrossRef]

47. Kurka, T. Application of the analytic hierarchy process to evaluate the regional sustainability of bioenergy developments. Energy 2013, 62, 393-402. [CrossRef]

48. Yedla, S.; Shrestha, R.M. Multi-criteria approach for the selection of alternative options for environmentally sustainable transport system in Delhi. Transp. Res. Part A Policy Pract. 2003, 37, 717-729. [CrossRef]

49. Kaya, T.; Kahraman, C. Multicriteria renewable energy planning using an integrated fuzzy VIKOR \& AHP methodology: The case of Istanbul. Energy 2010, 35, 2517-2527. [CrossRef]

50. Yazdani-Chamzini, A.; Fouladgar, M.M.; Zavadskas, E.K.; Moini, S.H.H. Selecting the optimal renewable energy using multi criteria decision making. J. Bus. Econ. Manag. 2013, 14, 957-978. Available online: https://www.tandfonline.com/doi/abs/10.3 846/16111699.2013.766257 (accessed on 6 April 2021). [CrossRef]

51. Meixner, O. In Fuzzy AHP group decision analysis and its application for the evaluation of energy sources. In Proceedings of the 10th International Symposium on the Analytic Hierarchy/Network Process, Pittsburgh, PA, USA, 29 July-1 August 2009; pp. 2-16. Available online: https://www.researchgate.net/profile/Oliver_Meixner/publication/255595355_FUZZY_AHP_ GROUP_DECISION_ANALYSIS_AND_ITS_APPLICATION_FOR_THE_EVALUATION_OF_ENERGY_SOURCES/links/02e7 e52fcd98dc06b1000000.pdf (accessed on 6 April 2021).

52. Ahmad, S.; Tahar, R.M. Selection of renewable energy sources for sustainable development of electricity generation system using analytic hierarchy process: A case of Malaysia. Renew. Energy 2014, 63, 458-466. [CrossRef]

53. Saaty, T.L. A scaling method for priorities in hierarchical structures. J. Math. Psychol. 1977, 15, 234-281. [CrossRef]

54. Saaty, T.L. How to make a decision: The analytic hierarchy process. Interfaces 1994, 24, 9-26. [CrossRef]

55. Aczél, J.; Saaty, T.L. Procedures for synthesizing ratio judgements. J. Math. Psychol. 1983, 27, 93-102. [CrossRef]

56. Blanquero Bravo, R.; Carrizosa Priego, E.J.; Conde Sánchez, E. Inferring efficient weights from pairwise comparison matrices. Math. Methods Oper. Res. 2006, 64, 271-284. [CrossRef]

57. Duleba, S.; Moslem, S. Examining Pareto optimality in analytic hierarchy process on real Data: An application in public transport service development. Expert Syst. Appl. 2019, 116, 21-30. [CrossRef] 
58. Duleba, S.; Tettamanti, T.; Nyerges, Á.; Szalay, Z. Ranking the key areas for autonomous proving ground development using Pareto Analytic Hierarchy Process. IEEE Access 2021, 9, 51214-51230. [CrossRef]

59. Ertan Özgüzer, G.; Oğuş-Binatlı, A. Economic convergence in the EU: A complexity approach. East Eur. Econ. 2016, 54, 93-108. [CrossRef]

60. Neagu, O.; Teodoru, M.C. The relationship between economic complexity, energy consumption structure and greenhouse gas emission: Heterogeneous panel evidence from the EU countries. Sustainability 2019, 11, 497. [CrossRef]

61. Bluszcz, A. European economies in terms of energy dependence. Qual. Quant 2017, 51, 1531-1548. [CrossRef] [PubMed]

62. Fitzmaurice, J. Damming the Danube: Gabcikovo/Nagymaros and Post-Communist Politics in Europe; Routledge: London, UK, 2018; ISBN 978-0813336282.

63. Németh, K.; Birkner, Z.; Katona, A.; Göllény-Kovács, N.; Bai, A.; Balogh, P.; Gabnai, Z.; Péter, E. Can Energy be a "Local Product” Again? Hungarian Case Study. Sustainability 2020, 12, 1118. [CrossRef]

64. Smith, P.J.; Jamiyansuren, B.; Kitsuki, A.; Yang, J.; Lee, J. Determinants of comparative advantage in GMO intensive industries. World Trade Rev. 2018, 17, 427-449. [CrossRef]

65. Formadi, K.; Mayer, P.; Pénzes, E. Geography of Tourism in Hungary. In The Geography of Tourism of Central and Eastern European Countries; Springer: Berlin/Heidelberg, Germany, 2017; pp. 189-232.

66. Borovsky, Y.V. International Rivalry in The Energy Sector: The Eastern European Market of Atomic Energy in Focus. Mgimo Rev. Int. Relat. 2017, 5, 114-129. [CrossRef]

67. Honvári, P.; Kukorelli, I.S. Examining the renewable energy investments in Hungarian rural settlements: The gained local benefits and the aspects of local community involvement. Eur. Ctry. 2018, 10, 74-88. [CrossRef]

68. Vegetti, F. The political nature of ideological polarization: The case of Hungary. ANNALS Am. Acad. Political Soc. Sci. 2019, 681, 78-96. [CrossRef]

69. Wu, J. Land Use Changes: Economic, Social, and Environmental Impacts. Choices 2008, 23, 6-10. Available online: https: //www.fs.usda.gov/treesearch/pubs/35453 (accessed on 6 April 2021).

70. Halsnæs, K.; Trærup, S. Development and climate change: A mainstreaming approach for assessing economic, social, and environmental impacts of adaptation measures. Env. Manag. 2009, 43, 765-778. [CrossRef]

71. Waisová, Š. The Environmental Situation in the Visegrad Region: Neglect and Insufficient Cooperation in the Face of Serious Environmental Threats. Politics Cent. Eur. 2018, 14, 57-73. [CrossRef]

72. Csatári, B.; Farkas, J.Z.; Lennert, J. Agrarian and rural development in Hungary after 1989. In Three Decades of Transformation in the East-Central European Countryside; Springer: Cham, Switzerland, 2019; pp. 21-54.

73. Baláž, P.; Zábojník, S.; Hričovský, M. EU fossil fuel imports and changes after Ukrainian crisis. In SHS Web of Conferences; EDP Sciences: Les Ulis, France, 2020; p. 05005. [CrossRef]

74. Rydzewski, P. Social Dimensions of Sustainable Development in International Public Opinion. Probl. Ekorozw. $2019,14,53-62$. Available online: https:/ /yadda.icm.edu.pl/baztech/element/bwmeta1.element.baztech-942a0817-ffa5-4352-89a9-e923df0cb7dd (accessed on 6 April 2021).

75. Annus, I. Tourism, self-representation and national identity in post-socialist Hungary. In Negotiating Identities; Brill Rodopi: Leiden, The Netherlands, 2011; pp. 1-23.

76. Howley, P. Landscape aesthetics: Assessing the general publics' preferences towards rural landscapes. Ecol. Econ. 2011, 72, 161-169. [CrossRef]

77. Streimikiene, D. Comparative assessment of environmental indicators of quality of life in Romania and Lithuania. Econ. Sociol. 2014, 7, 11. [CrossRef]

78. Sagar, A.D.; Najam, A. The human development index: A critical review. Ecol. Econ. 1998, 25, 249-264. [CrossRef]

79. Lawn, P.A. A theoretical foundation to support the Index of Sustainable Economic Welfare (ISEW), Genuine Progress Indicator (GPI), and other related indexes. Ecol. Econ. 2003, 44, 105-118. [CrossRef]

80. Kasperowicz, R.; Štreimikienè, D. Economic growth and energy consumption: Comparative analysis of V4 and the "old" EU countries. J. Int. Stud. 2016, 9, 181-194. [CrossRef]

81. Tirkolaee, E.B.; Hosseinabadi, A.A.R.; Soltani, M.; Sangaiah, A.K.; Wang, J. A hybrid genetic algorithm for multi-trip green capacitated arc routing problem in the scope of urban services. Sustainability 2018, 10, 1366. [CrossRef]

82. Paksoy, T.; Bektaş, T.; Özceylan, E. Operational and environmental performance measures in a multi-product closed-loop supply chain. Transp. Res. Part E Logist. Transp. Rev. 2010, 47, 532-546. [CrossRef]

83. Weinschenck, G. Der ökonomische oder der ökologische Weg [The economic or the ecologic way?]. Ger. J. Agric. Econ. Agrarwirtsch. 1986, 35, 321-327. [CrossRef]

84. Luca, F.-A.; Epuran, G.; Ciobanu, C.-I.; Horodnic, A.V. Green Jobs Creation-Main Element in the Implementation of Bioeconomic Mechanisms. Amfiteatru. Econ. 2019, 21, 60-74. Available online: https://www.ceeol.com/search/article-detail?id=734471 (accessed on 6 April 2021).

85. Mironenko, M.Y.; Poleva, O. The socio-economic importance of bioenergy and prospects for innovative breakthrough. Investig. Pract. Exp. 2016, 7, 24-29. [CrossRef]

86. Igliński, B.; Iglińska, A.; Kujawski, W.; Buczkowski, R.; Cichosz, M. Bioenergy in Poland. Renew. Sustain. Energy Rev. 2011, 15, 2999-3007. [CrossRef] 
87. Popp, J. KAP-reform és a többfunkciós mezőgazdaság. GAZDÁLKODÁS Sci. J. Agric. Econ. 2003, 47, 48-69. Available online: https://ageconsearch.umn.edu/record/225559/ (accessed on 6 April 2021).

88. Oláh, J.; Krisán, E.; Kiss, A.; Lakner, Z.; Popp, J. PRISMA Statement for Reporting Literature Searches in Systematic Reviews of the Bioethanol Sector. Energies 2020, 13, 2323. [CrossRef]

89. Yu, X.; Luo, H.; Wang, H.; Feil, J.-H. Climate change and agricultural trade in central Asia: Evidence from Kazakhstan. Ecosyst. Health Sustain. 2020, 6, 1766380. [CrossRef]

90. Kern, A.; Barcza, Z.; Marjanović, H.; Árendás, T.; Fodor, N.; Bónis, P.; Bognár, P.; Lichtenberger, J. Statistical modelling of crop yield in Central Europe using climate data and remote sensing vegetation indices. Agric. Meteorol. 2018, 260, 300-320. [CrossRef]

91. Arodudu, O.; Holmatov, B.; Voinov, A. Ecological impacts and limits of biomass use: A critical review. Clean Technol. Environ. Policy 2020, 22, 1591-1611. [CrossRef]

92. European Commission. A Sustainable Bioeconomy for Europe: Strengthening the Connection between Economy, Society and the Environment Updated BIOECONOMY Strategy; Publications Office of the European Union: Luxembourg, 2018; pp. 1-107. Available online: https: / /op.europa.eu/en/publication-detail/- / publication/edace3e3-e189-11e8-b690-01aa75ed71a1/languageen/format-PDF/source-149755478 (accessed on 6 April 2021). [CrossRef]

93. Deane, J.P.; Pye, S. Europe's ambition for biofuels in aviation-A strategic review of challenges and opportunities. Energy Strategy Rev. 2018, 20, 1-5. Available online: http:/ /www.sciencedirect.com/science/article/pii/S2211467X1730086X (accessed on 6 April 2021). [CrossRef]

94. De LTOliveira, G.; McKay, B.; Plank, C. How biofuel policies backfire: Misguided goals, inefficient mechanisms, and politicalecological blind spots. Energy Policy 2017, 108, 765-775. [CrossRef]

95. Sata, R.; Karolewski, I.P. Caesarean politics in Hungary and Poland. East Eur. Politics 2020, 36, 206-225. [CrossRef]

96. Banimostafa, A.; Nguyen, T.T.H.; Kikuchi, Y.; Papadokonstantakis, S.; Sugiyama, H.; Hirao, M.; Hungerbühler, K. Safety, health, and environmental assessment of bioethanol production from sugarcane, corn, and corn stover. Green Process. Synth. 2012, 1, 449-461. [CrossRef]

97. Kheybari, S.; Kazemi, M.; Rezaei, J. Bioethanol facility location selection using best-worst method. Appl. Energy 2019, $242,612-623$. [CrossRef]

98. López-Aparicio, S.; Hak, C. Evaluation of the use of bioethanol fuelled buses based on ambient air pollution screening and on-road measurements. Sci. Total Environ. 2013, 452, 40-49. [CrossRef] [PubMed] 